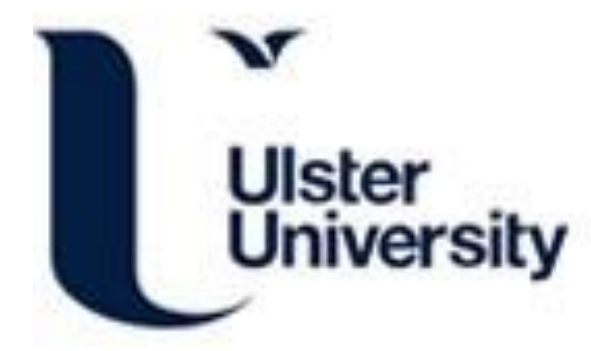

\title{
Defining Industrial Action
}

Creighton, B., Denvir, C., \& McCrystal, S. (2019). Defining Industrial Action. Federal Law Review, 45(3), 383414. https://doi.org/10.22145/flr.45.3.2

Link to publication record in Ulster University Research Portal

\author{
Published in: \\ Federal Law Review
}

Publication Status:

Published (in print/issue): 18/03/2019

DOI:

10.22145/flr.45.3.2

\section{Document Version}

Author Accepted version

\section{General rights}

Copyright for the publications made accessible via Ulster University's Research Portal is retained by the author(s) and / or other copyright owners and it is a condition of accessing these publications that users recognise and abide by the legal requirements associated with these rights.

\section{Take down policy}

The Research Portal is Ulster University's institutional repository that provides access to Ulster's research outputs. Every effort has been made to ensure that content in the Research Portal does not infringe any person's rights, or applicable UK laws. If you discover content in the Research Portal that you believe breaches copyright or violates any law, please contact pure-support@ulster.ac.uk. 


\title{
DEFINING INDUSTRIAL ACTION
}

\author{
Breen Creighton,* Catrina Denvir** and Shae McCrystal***
}

\section{Introduction}

\section{AN EMAIL WRITTEN IN CAPS LOCK IS AN IRRITATION TO THE RECIPIENT AND} CAN DISRUPT THE EFFICIENT FUNCTIONING OF A BUSINESS. ${ }^{1}$ Customer services officers wearing union t-shirts, or airline pilots interrupting passengers to tell them about an industrial campaign, can be marginal inconveniences to the customers of a business. But the legal status of these annoyances or inconveniences can be of great significance to the operation of the bargaining regime put in place by the Fair Work Act 2009 (Cth) (FW Act). That is because the question of whether such conduct constitutes 'industrial action' within the definition of that term in s 19 of the FW Act can have significant legal consequences.

First, in a common law jurisdiction like Australia, most, if not all, worker industrial action would be unlawful as either or both of a tort and a breach of the worker's contract of employment. Historically, it was commonly also unlawful under statute. ${ }^{2}$ The FW Act now provides some protection against common law and statutory liability for unions and employees who engage in industrial action in the context of negotiations for a singleenterprise agreement, but the protection extends only to action which falls within the s 19 definition. Any action which falls outside that definition will almost invariably be unlawful at common law and/or statute.

Second, many (but not all) of the statutory liabilities for unprotected industrial action under the FW Act turn upon whether the conduct in question falls within the statutory definition. For example, s 418 of the FW Act enables an employer confronted by unprotected industrial action to seek an order from the FWC requiring that the action cease or not occur. Such orders can, in turn, be enforced in the Federal Court. ${ }^{3}$

\footnotetext{
* Graduate School of Business and Law, RMIT University.

** Director, Ulster Legal Innovation Centre, Ulster University.

*** The University of Sydney School of Law, University of Sydney. The authors would like to thank the audience participants at the Australian Labour Law Association Conference held in Melbourne in November 2016 and the anonymous referees for helpful comments on an earlier version of this paper.

${ }^{1}$ For example, because communications need to be recalibrated $b$ efore they can be sent to clients or customers of the employer.

${ }^{2}$ For discussion of these historical exposures, see Andrew Stewart, Anthony Forsyth, Mark Irving, Richard Johnstone \& Shae McCrystal, Creighton \& Stewart's Labour Law, 6 ${ }^{\text {th }}$ ed, (Federation Press, 2016) [3.05][3.19]. For discussion of contemporary exposures see ibid, [26.11]-[26.106].

${ }^{3}$ Such action may also be unlawful at common law and/or under provisions such as ss $30 \mathrm{~J}$ and $30 \mathrm{~K}$ of the Crimes Act 1914 (Cth) or ss 45D-45EA of the Competition and Consumer Act 2010 (Cth). See further Stewart et al, above n 2, ch 26; Carolyn Sappideen, Paul O'Grady \& Joellen Riley, Macken 's Law of Employment, $8^{\text {th }}$ ed, (Lawbook Co., 2016) [14.80]-[14.410]; Marilyn Pittard \& Richard Naughton, Australian Labour and Employment Law (Lexis Nexis, 2015) ch 18.
} 
Third, the FW Act makes it unlawful for an employer to pay wages in respect of a period where an employee has engaged in industrial action, and for an employee to seek or to accept such payment. ${ }^{4}$ Any lack of clarity around whether action constitutes industrial action could leave the employer or employees facing civil penalties where payment was not withheld for action that did constitute industrial action, whilst an employer could face penalties if they withheld wages in respect of action which did not fall within the statutory definition.

Finally, s 524 of the FW Act permits an employer to stand down an employee without pay in circumstances (inter alia) where the employee 'cannot usefully be employed because of ... industrial action' (other than that employer's own industrial action). Here, the ability of employees who are not themselves taking industrial action to earn wages may turn on whether or not the conduct of co-workers, or the employees of another business altogether, falls within the s 19 definition.

Manifestly, therefore, clarity in the definition of industrial action under the FW Act is of critical practical significance for a range of parties. As the examples outlined above demonstrate, unions engaged in enterprise bargaining under the FW Act often exhibit considerable creativity in the forms of industrial action they take in order to pressure employers to accede to their demands - preferably with minimum loss of income or other inconvenience for the employees concerned. Such creativity is pushing at the boundaries of the statutory definition, and one of the principal findings of this article is that the definition is increasingly unfit for purpose.

The meaning and effect of the term 'industrial action' has been examined by a number of authors in a number of contexts. ${ }^{5}$ However, there has not so far been any in-depth examination of the current definition in its social, historical or international context. With that in mind, this is article starts with an examination of the concept of 'industrial action'. It then traces the approach to definition of industrial action (and cognate terms) in Australia over the years, culminating in s 19 of the FW Act. ${ }^{6}$ This is followed by a detailed examination of the meaning and effect of s 19 as it has been applied by the courts and tribunals.

This examination clearly suggests that the s 19 definition is fundamentally flawed both in principle and in practice. This is largely a consequence of the fact that it is very much the product of a regulatory regime that was directed to the proscription of industrial action rather than its protection. The FW Act now purports both to proscribe and to protect. As indicated, it adopts a definition that is not fit for either purpose. As a result, it is almost impossible for stakeholders to determine what forms of industrial action are and are not

\footnotetext{
${ }^{4}$ There are, however, qualifications to this in respect of partial work bans. See generally Stewart et al, above $n$ 2, [26.56]-[26.69].

${ }^{5}$ See, eg, Stewart et al, above n 2, [26.20]-[26.27]; Shae McCrystal, The Right to Strike in Australia (Federation Press, 2010), 112-19, 242-43.

${ }^{6}$ Legislation in all of the States except Tasmania and Victoria includes definitions of 'industrial action' - see Industrial Relations Act 1996 (NSW) s 4 and Dictionary; Industrial Relations Act 1999 (Qld) s 4 and Schedule 5; Fair Work Act 1994 (SA) s 4; and Industrial Relations Act 1979 (WA) s 7. With the referral of legislative power by all jurisdictions apart from Western Australia, the State definitions are now of limited practical relevance, and are not examined in this article.
} 
legally permissible, or to ascertain what are to be the legal and other consequences of engaging in certain forms of industrial conduct. The legislation also denies protection to certain forms of worker behaviour that ought to be protected to ensure that Australia gives proper effect to its obligations in international law. Bearing these considerations in mind, the authors offer a number of suggestions for an approach to the definition of industrial action that address the ambiguities and conceptual confusion that characterise the current provision.

\section{What is 'industrial action'?}

\subsection{The Concept}

According to the Macquarie Dictionary 'industrial action' comprises 'organised disruptive action, as a strike or go-slow, taken by a group of workers, to promote what they conceive to be either their own interests or the general public good'.

This encapsulates the key elements of the commonplace understanding of industrial action:

- it is collective in character;

- it involves workers, usually organised in a trade union;

- it is intended to be disruptive - for example by halting or interfering with productive activity;

- it is purposive or coercive in that its principal purpose is to exert pressure on the target of the action (most obviously an employer) to accede to the demands of the workers who are taking the action; and

- it is primarily motivated by self-interest, although occasionally worker participants may be motivated by more altruistic concerns. Self-interest could clearly include seeking improvements in terms and conditions of employment or protecting work practices or job security. Altruistic drivers could include environmental protection or protest against the exploitation of children or young persons in overseas workplaces. ${ }^{7}$

The most obvious form of industrial action is the strike - what the Macquarie describes as 'a concerted stopping of work or withdrawal of workers' services in order to compel an employer to accede to demands or in protest against terms and conditions imposed by an employer'. Indeed, in many respects the term 'industrial action' can be regarded as coterminous with 'strike', especially if that term is accorded the kind of expanded interpretation which, as appears below, has been adopted by the International Labour Organisation (ILO).

However characterised, industrial action can encompass a wide range of activities which go beyond the dictionary definition of 'strike'. They include:

\footnotetext{
${ }^{7}$ See, eg, 'Green bans revived to halt redevelopment of iconic Bondi building', Workplace Express, 31 May 2016; 'Mundey re-emerges for new Rocks green bans', Workplace Express, 16 September 2016.
} 
- a go-slow or work-to-rule, where workers continue to perform work but do so at a reduced pace. Often this is achieved by means of a strict adherence to the rules of the workplace ${ }^{8}$

- partial work bans, where workers impose restrictions on the performance of certain parts of the job with a view to disrupting the normal course of the employer's business;

- posting pickets at or near an employer's workplace with one or more of a number of objectives, including: trying to persuade fellow-workers not to work; encouraging clients or customers of the target employer not to do business with the target; or disrupting the passage of goods, services or people into or out of the workplace;

- boycotting goods or services emanating from, or destined for, a particular source;

- industrial sabotage, for example by facilitating a breakdown of machinery or a coordinated failure to report for work because of 'illness'; and

- occupation of workplaces.

Interestingly, the Macquarie definition does not contemplate industrial action by employers. Clearly, however, employers can and do take industrial action, either to promote their own interests and/or to respond to action by employees. Most obviously, this would include a lockout, which the Macquarie defines as 'the closing of a business, or wholesale dismissal of employees by the employer because the employees refuse to accept his terms or because the employer refuses to operate on terms set by a union'.

Employer industrial action can, however, take a number of other forms, including: denial of opportunities to work overtime; withholding non-contractual bonus payments; relocation of a business; and directing investment decisions away from industrially militant workplaces. As appears below, the FW Act accords only very limited recognition to the capacity of employers to take industrial action, whilst international standards on the right to strike do not require that there be formal recognition of the right of employers to take industrial action, although nor do they proscribe it.

\subsection{ILO Standards}

Neither the Freedom of Association and Protection of the Right to Organise Convention, 1948 (No 87) nor the Right to Organise and Collective Bargaining Convention, 1949 (No 98) make any express reference to 'industrial action' or indeed to the right to strike. Nevertheless, the Committee of Experts on the Application of Conventions and Recommendations (CEACR) has consistently read articles 3, 8 and 10 of Convention No 87 as protecting the right to strike, ${ }^{9}$ although it should be noted that this reading of Convention No 87 has come under increasing criticism by employer representatives, and some governments, in recent

\footnotetext{
${ }^{8}$ See eg Secretary of State for Employment $v$ Associated Society of Locomotive Engineers and Firemen (No 2) [1972] 2 QB 455.

${ }^{9}$ See Ruth Ben-Israel, International Labour Standards: The Case of Freedom to Strike (Kluwer, 1987); Tonia Novitz, International and European Protection of the Right to Strike (OUP, 2003) 110-20. As to the substance of the jurisprudence see Bernard Gernigon, Alberto Odero and Horacio Guido, ILO Principles Concerning the Right to Strike (ILO, 2000) (see also (1998) 137 ILR 441); McCrystal, above n 5, ch 2.
} 
years. ${ }^{10}$ Nevertheless, it remains the case that both Convention No 87, and the principles of freedom of association as applied by the Governing Body's Committee on Freedom of Association (CFA), affords protection to a broadly drawn notion of the right to strike. ${ }^{11}$

It is also important to note that art 8(1)(d) of the International Covenant on Economic, Social and Cultural Rights (ICESCR) expressly protects 'the right to strike', 'provided it is exercised in conformity with the laws of the particular country'.

In the ILO context, both the CEACR and the CFA have acknowledged that the internationally protected right to strike includes other forms of industrial action such as 'wildcat strikes, tools-down, go-slow, working to rule and sit-down strikes' ${ }^{12}$ The CEACR has specifically indicated that picketing and occupying workplaces constitute the legitimate exercise of the right to strike - subject to the qualifier that the action concerned must be peaceful. ${ }^{13}$

It is clear, therefore, that the right to strike as recognised by the supervisory bodies of the ILO encompasses a wide range of worker actions which are intended to exert pressure upon employers in an industrial context, and upon governments and other parties concerning 'economic and social policy questions' and 'labour problems of any kind which are of direct concern to the workers'. ${ }^{14}$ Thus understood, the ILO jurisprudence concerning the right to strike appears to provide an appropriate reference point for an analysis of the approach to 'industrial action' that has been adopted in Australia - especially in light of the fact that this country is required to respect the principles of freedom of association by virtue of its membership of the ILO, and must give effect to the requirements of Convention No 87 and Art $8(1)(d)$ of the ICESCR by virtue of its ratification of those instruments.

The right to strike as recognised by the ILO does not extend to employer lockouts. The same is true for the ICESCR. ${ }^{15}$ None of this means that recognition of the capacity to lockout in national law and practice is inherently inconsistent with the internationally

\footnotetext{
${ }^{10}$ See, for example, Novitz, above n 9, 120-23; Claire La Hovary, 'Showdown at the ILO? A Historical Perspective on the Employers' Group's Challenge to the Right to Strike' (2013) 42 Industrial Law Journal 338. ${ }^{11}$ See ILC, Freedom of Association and Collective Bargaining: General Survey by the Committee of Experts on the Application of Conventions and Recommendations, $69^{\text {th }}$ Session, 1983, Report III (Part 4B), [200] (1983 General Survey). See also ILC, Freedom of Association and Collective Bargaining: General Survey by the Committee of Experts on the Application of Conventions and Recommendations, $81^{\text {st }}$ Session, 1994, Report III (Part 4B), [147]-[151] (1994 General Survey); ILC, Giving globalisation a human face: General Survey on the fundamental Conventions concerning rights at work in light of the ILO Declaration on Social Justice for a Fair Globalisation, 2008, 101 ${ }^{\text {st }}$ Session, 2012, Report III (Part 1B), [117] (2012 General Survey).

${ }^{12} \mathrm{ILO}$, Digest of decisions and principles of the Freedom of Association Committee of the Governing Body of the ILO, $5^{\text {th }}$ ed (ILO, 2006) [545]-[546] (Digest); 1994 General Survey, above n 11, [173]. Paragraph 126 of the 2012 General Survey is to the same effect.

${ }^{13}$ Ibid, [174]. See further ATJM Jacobs, 'The Law of Strikes and Lockouts', in Roger Blanpain (ed), Comparative Labour Law and Industrial Relations in Industrialised Market Economies, XIth ed (Wolters Kluwer, 2014) 759-62.

${ }^{14}$ Both Committees consider that purely political strikes do not fall within the scope of the right to strike - see 1994 General Survey, above n 11, [165]; 2012 General Survey, above n 11, [124]; Digest, above n 12, [528][529].

${ }^{15}$ In Victoria v Commonwealth (1996) 187 CLR 416, 547 the High Court found that provisions in the Industrial Relations Act 1988 (Cth) (IR Act) (as amended in 1993) protecting the employer right to lock out were not 'reasonably capable of being seen as appropriate and adapted' to giving effect to the right to strike as required by $\operatorname{Art} 8(1)(d)$.
} 
recognised right to strike: indeed, international standards implicitly recognise the legitimacy of the lock out in certain contexts. ${ }^{16}$ It remains the case, however, that the capacity to lockout is not explicitly protected by international law.

\section{The Origins of section 19 of the FW Act}

\subsection{The Conciliation and Arbitration Act 1904}

The C\&A Act as originally enacted did not contain any reference to, let alone definition of, 'industrial action', and did not afford any protection against common law liability in respect of such action. On the contrary, it made both strikes and lockouts criminal offences, punishable by a fine of up to $£ 1,000 .^{17}$

'Strike' for this purpose included 'the total or partial cessation of work by employees, acting in combination, as a means of enforcing compliance with demands made by them or other employees on employers', whilst a 'lockout' included 'the closing of a place or a part of a place of employment, or the total or partial suspension of work by an employer, with a view to compel his employees, or to aid another employer in compelling his employees, to accept any term or condition of employment'. ${ }^{18}$

The statutory prohibition of strikes and lockouts was repealed in $1930,{ }^{19}$ and although the legislation remained extremely hostile to industrial action of any kind, it no longer made specific reference to either strikes or lockouts. ${ }^{20}$ The C\&A Act did, however, contemplate the inclusion in awards of provisions prohibiting a union bound by an award from being concerned, directly or indirectly, in any ban or limitation on the performance of work in accordance with that award. ${ }^{21}$ These provisions were commonly referred to as 'bans clauses', and were extensively relied upon, especially in the 1950s and '60s, as a means of trying to enforce the norms of the system of conciliation and arbitration. They fell into disuse following the 'Clarrie O'Shea affair' in 1969. This incident involved the imprisonment for contempt of court of a union official for refusing to facilitate the collection of fines which had been imposed on his union in respect of numerous breaches of bans clauses. O'Shea was released from prison after an anonymous benefactor paid the outstanding fines. ${ }^{22}$

\footnotetext{
${ }^{16}$ See, eg, the ILO's Voluntary Conciliation and Arbitration Recommendation 1951 (No 92), cl 3(4). See also Digest, above n 12, [600], [853]. See also Jacobs, above n 13, 784-86.

${ }^{17}$ C\&A Act s 6.

${ }^{18}$ C\&A Act s 4. For detailed discussion of the legal definitions of strike and lockout in Australian statute law, see Edward I Sykes, Strike Law in Australia, $2^{\text {nd }}$ ed, (Law Book Co, 1982) ch 6.

${ }^{19}$ Commonwealth Conciliation and Arbitration Act 1930 s 4 repealed the definitions of strike and lockout, whilst s 6 repealed the statutory proscription of such conduct.

${ }^{20}$ For judicial consideration of the nature of a strike see McKernan v Fraser (1931) 46 CLR 343, 360-61 (per Dixon J), 372-78 (per Evatt J); Kidd v Savage River Mines (1984) 6 FCR 398, 404-06 (per Gray J).

${ }^{21}$ The C\&A Act did not contain any definition of 'ban', although up until 1977 it did contain a definition of 'work ban' for the limited purpose of the compulsory ballot provision in the then s 45 - see further $\mathrm{n} 24$, below.

${ }^{22}$ Interestingly, the contempt was never formally purged. For discussion see Jack Hutson, Penal Colony to Penal Powers, rev ed, (Amalgamated Metal Workers' and Shipwrights' Union, 1983) 265-80; WB Creighton, WJ Ford and RJ Mitchell, Labour Law: Text and Materials, $2^{\text {nd }}$ ed (Law Book Company, 1993) 833-40.
} 
Bans clauses were abolished by the Workplace Relations and Other Legislation Amendment Act 1996 (WROLA Act).

\subsection{The Conciliation and Arbitration Amendment Act (No 3) 1977}

Not only did the C\&A Act lack any definition of strike or lockout after 1930, it also lacked any definition of 'industrial action', despite the fact that it contained many provisions that were clearly directed at the proscription of many of the behaviours encompassed by that term.

That changed in 1977, when the Conciliation and Arbitration Amendment Act (No 3) 1977 (1977 Act) for the first time introduced a definition of 'industrial action' in federal law:

'Industrial action' means -

(a) the performance of work (being work the terms and conditions of which are prescribed wholly or partly by an award of the [Australian Conciliation and Arbitration] Commission...) in a manner different from that in which it is customarily performed, or the adoption of a practice in relation to such work, the result of which is a restriction or limitation on, or delay in, the performance of work;

(b) a ban, limitation or restriction on the performance of work, or on acceptance or offering for work, in accordance with the terms and conditions prescribed by an award of the Commission...or

(c) a failure or refusal by persons to attend for work or a failure or refusal to perform any work at all by persons who attend for work,

but does not include the performance of work in a manner, the adoption of a practice, ban, limitation or restriction, or a failure or refusal, which is authorised by the employer of the persons concerned. ${ }^{23}$

The 1977 amendments were introduced some 15 years before the start of the formal shift away from conciliation and arbitration towards enterprise bargaining. They were not, therefore, concerned with protecting workers and unions against common law or statutory liability in respect of industrial action. Instead, they were concerned with enforcing the norms of the system through provisions enabling the balloting of union members in relation to proposed industrial action, ${ }^{24}$ or the deregistration of trade unions who took industrial action in certain circumstances. ${ }^{25}$ They were also concerned with protecting individuals who did not wish to join, or participate in the activities of, trade unions. ${ }^{26}$

The 1977 definition of industrial action provided the basis for the definitions of that term in all subsequent iterations of the federal industrial statute, including s 19 of the FW Act. ${ }^{27}$

Since 1993, however, these definitions have, to a significant degree, been concerned with determining the scope of statutory protection against common law liability in respect of industrial action, as well as fixing unions and their members with liability for the kinds of activities that were the focus of the 1977 amendments. In addition, the updated versions of the 1977 definition have been used since 1996 to proscribe industrial action that does not fall within the statutory protections. Despite these important changes of purpose, the statutory

\footnotetext{
${ }^{23}$ C\&A Act s 4, as amended by s 3 of the 1977 Act.

${ }^{24}$ C\&A Act s 45.

${ }^{25}$ C\&A Act s 143(1)(j).

${ }^{26}$ C\&A Act ss 5(1)(aa), 132A, 144A. See further Phillipa Weeks, Trade Union Security Law (Federation Press, 1996) 178 - 188; Creighton et al, above n 22, 1081-89.

${ }^{27}$ Section 7(1) of the Building and Construction Industry (Improving Productivity) Act 2016 (Cth) (BCIIP Act) defines 'industrial action' for purposes of that Act in terms which are effectively identical to the definition in $\mathrm{s}$ 19(1) of the FW Act.
} 
definition has remained essentially unchanged for some 40 years. That being the case, it is not entirely surprising that it should now be found wanting.

\section{Section 19}

\subsection{The core concept}

Section 19 of the FW Act states:

(1) Industrial action means action of any of the following kinds:

(a) the performance of work by an employee in a manner different from that in which it is customarily performed, or the adoption of a practice in relation to work by an employee, the result of which is a restriction or limitation on, or a delay in, the performance of the work;

(b) a ban, limitation or restriction on the performance of work by an employee or on the acceptance of or offering for work by an employee;

(c) a failure or refusal by employees to attend for work or a failure or refusal to perform any work at all by employees who attend for work;

(d) the lockout of employees from their employment by the employer of the employees.

Note: In Automotive, Food, Metals, Engineering, Printing and Kindred Industries Union $v$ The Age Company Limited, PR946290, the Full Bench of the Australian Industrial Relations Commission considered the nature of industrial action and noted that action will not be industrial in character if it stands completely outside the area of disputation and bargaining.

(2) However, industrial action does not include the following:

(a) action by employees that is authorised or agreed to by the employer of the employees;

(b) action by an employer that is authorised or agreed to by, or on behalf of, employees of the employer;

(c) action by an employee if:

(i) the action was based on a reasonable concern of the employee about an imminent risk to his or her health and safety; and

(ii) the employee did not unreasonably fail to comply with a direction of his or her employer to perform other available work, whether at the same or another workplace, that was safe and appropriate for the employee to perform.

(3) An employer locks out employees from their employment if the employer prevents the employees from performing work under their contracts of employment without terminating those contracts.

Self-evidently, this definition is very similar to that in the 1977 Act. The most significant differences relate to: the scope of the exclusions in s 19(2); the inclusion of a definition of 'lockout' in s 19(3); and the inclusion in s 19(1)(a) and (b) of reference to work 'performed by an employee' rather than to work regulated by an award as in the 1977 definition.

\subsection{The significance of the definition}

As indicated at the outset, the definition of industrial action in s 19 is of critical significance in relation to four principal issues.

\subsubsection{Protected industrial action}

Section 408 of the FW Act identifies three forms of protected industrial action: employee claim action, employee response action, and employer response action. To be protected, all such action must be 'for a proposed enterprise agreement'. It must also meet a set of 'common requirements' set out in s 413 . Furthermore, before there can be any question of 
taking protected industrial action, the proposed action must have been approved in a ballot conducted in accordance with Division 8 of Part $3-3 .^{28}$

If the preconditions are satisfied, then s 415 has the effect that 'no action lies under any law (whether written or unwritten) in force in a State or Territory in relation to any industrial action that is protected industrial action', subject to the qualification that protection will not extend to any action involving: personal injury; wilful or reckless destruction of, or damage to, property; the unlawful taking, keeping or use of property; or defamation that occurs in the course of the industrial action.

The fact that industrial action is protected has a number of important consequences for individual participants. Quite apart from the protection against common law or statutory liability in s 415, it is clear from s 347(1)(b)(iii) that organising or participating in protected industrial action constitutes 'industrial activity' for purposes of Division 4 of Part 3-1, with the consequence that the individual is protected against 'adverse action' because of their having organised or participated in the protected industrial action. ${ }^{29}$

An employee who is dismissed for participating in unprotected industrial action cannot access the protections in Part 3-1 of the FW Act, but might still be able to challenge the fairness of their dismissal under the unfair dismissal provisions in Part 3-2 of that Act. ${ }^{30}$

\subsubsection{Unprotected industrial action}

As noted earlier, for all practical purposes, all industrial action which is not subject to statutory protection is unlawful at common law as either or both of a tort or breach of contract.

Under the FW Act, the statutory proscriptions are narrower than in the past. Nevertheless, they do include: a prohibition on organising or engaging in industrial action during the nominal life of an enterprise agreement (s 417); ${ }^{31}$ provision enabling the FWC to make orders that unprotected industrial action which is happening, is threatened, impending or probable, or is being organised stop, not occur or not be organised (s 418); ${ }^{32}$ and the availability of injunctions to restrain or stop industrial action where a bargaining representative is engaging in pattern bargaining (s 422). ${ }^{33}$

\subsubsection{Payment of wages during industrial action}

\footnotetext{
${ }^{28}$ The authors' interest in the broader definitional issues addressed in this article emerged in the context of a detailed study of the operation of these ballot provisions which is being undertaken together with Richard Johnstone of QUT. This research is funded by the ARC - ARC DP140100902. For detailed discussion of the ballot provisions see Breen Creighton, Catrina Denvir and Shae McCrystal, 'Strike ballots and the law in Australia' (2016) 29 Australian Journal of Labour Law 154.

${ }^{29} \mathrm{FW}$ Act ss 346(b) and 342(1) Table, item 1.

${ }^{30}$ See further Stewart et al, above n 2, [26.72].

${ }^{31}$ When read with s 545, this section provides for the issue of injunctions, making of orders for compensation, orders of reinstatement and/or the imposition of penalties in respect of breaches of the prohibition.

${ }^{32}$ Failure to comply with such an order is enforceable by means of injunction in the Federal Circuit Court or Federal Court.

${ }^{33}$ This provision appears to be entirely unused in practice, see Stewart et al, above n 2, 934-5.
} 
Workers normally take industrial action to exert pressure on an employer with whom they are in dispute. To be effective, the action must inflict 'pain' upon the employer - for example in consequence of their being unable to supply goods or services to their clients or customers. It is generally accepted that workers must share in the pain, in particular by not receiving wages or salary whilst participating in industrial action.

Subject to one exception, the FW Act does not allow for the payment of wages in respect of periods of industrial action. ${ }^{34}$ This is reflected in Division 9 of Part 3-3, which makes almost obsessively detailed provision to prevent workers from seeking, receiving or accepting payment in relation to any period when they are taking industrial action - protected or otherwise. ${ }^{35}$ The solitary exception is where protected industrial action takes the form of a partial work ban, in which circumstances the employer may, but is not obliged, to withhold all or part of an employee's wages, or to refuse to accept part-performance from the employee. ${ }^{36}$ It should also be noted that an employer can quite properly pay wages to employees in circumstances where they have engaged in conduct which would constitute 'industrial action' but for the fact that the employer has 'agreed' to that action in accordance with s $19(2)(a) .^{37}$

\subsubsection{Stand down of employees}

In some circumstances, employers who are not directly involved in an industrial dispute may find that their business is disrupted by such action to the point where they cannot usefully deploy their workforce - for example because of a disruption in the supply chain. Section 524(1)(a) of the FW Act addresses this possibility by enabling employers to stand down their employees in such circumstances - provided the industrial action is not organised or engaged in by the employer. ${ }^{38}$ Section 524(3), meanwhile, provides that when a worker is stood down in reliance upon s 524(1) 'the employer is not required to make payments to the employee' for the period of the stand down.

If, as is commonly the case, an enterprise agreement makes provision for the standing down of employees in the event of industrial action, then the employer cannot stand down in reliance upon s 524(1), but can, of course, stand its employees down in accordance with the agreement. $^{39}$

\section{Industrial action under s 19}

\footnotetext{
${ }^{34}$ See further Stewart et al, above n 2, [26.58]-[26.69].

${ }^{35}$ Note also that the Social Security Act 1991 (Cth) provides for disqualification from receipt of social security benefits for persons whose employment is interrupted by their participation in industrial action. See, eg, ss 500C, 553A, 596, 660XBE, 729AA, 759 and 771HB. For an example of the practical application of the forerunners of these provisions, see Savage v Director General of Social Services 1983 AILR 525.

${ }^{36} \mathrm{FW}$ Act ss 471-472.

${ }^{37}$ See further text accompanying $\mathrm{n} 113$.

${ }^{38}$ Note that s 524(1)(b) and (c) provides for stand down in circumstances which are not industrial action-related.

${ }^{39} \mathrm{FW}$ Act s 524(2). On occasion, a contract of employment may provide for stand down in the face of industrial action, in which case the same principles will apply. See further Stewart et al, above n 2, [15.56].
} 
This section of the article consists of an examination of s 19(1) to ascertain exactly what is, and what is not, industrial action under the FW Act. Action constituting a strike is considered first, followed by action falling short of strike, notably work bans and the performance of work in a manner different from that in which it is customarily performed.

\section{$5.1 \quad$ Strikes}

It will be recalled that s 19(1)(c) provides that industrial action includes both 'a failure or refusal by employees to attend for work' and 'a failure or refusal to perform any work at all by employees who attend for work'.

This is entirely consistent with the dictionary definition of a strike as 'a concerted stopping of work or withdrawal of workers' services'. As such, it raises few difficulties in practice: it is normally a fairly straightforward question of fact whether workers have failed to attend for work, or have refused to perform any work having first attended for work. More problematic in both conceptual and practical terms are the attempts in s 19(1)(a) and (b) to capture action that does not involve a refusal to attend for, or perform, work.

\subsection{Industrial action short of a strike}

\subsubsection{Section 19(1)(b)}

Section 19(1)(b) contemplates 'a ban, limitation or restriction' on the performance of work, or on the 'acceptance of or offering for work', by an employee. There are, therefore, two limbs to this definition: the first contemplates a ban etc on the actual performance of work, whereas the second contemplates a refusal to offer for work or to accept work when offered. Clearly, there is some overlap between the second limb of para (b) and refusal to attend for, or perform, work as contemplated by para (c) discussed above. Paragraph (b) does, however, appear to be rather wider in that it does not seem to require that there actually be a stoppage of work, provided that the ban is in place.

There has been some confusion as to the meaning of a 'ban' for purposes of para (b). This is surprising in light of the fact that, as noted earlier, the concept of a ban has been a significant part of the federal system of industrial regulation for many years.

The confusion to which the use of 'bans' in s 19(1)(b) has given rise is illustrated by the decision of the Supreme Court of Victoria in Energy Australia Yallourn Pty Ltd $v$ CFMEU (Energy Australia). ${ }^{40}$ In that case the CFMEU had notified the employer that it proposed to impose 'bans limiting the output of individual generators' at a power station operated by Energy Australia to 240 megawatts at prescribed times of the day. The bans had been approved by a relevant protected industrial action ballot, but in considering the employer's application for an injunction on the basis that the proposed action was not a 'ban' within the meaning of s 19(1), and therefore not protected industrial action, Hollingworth J agreed with the employer's contention that 'the word "ban" contemplates a prohibition on work, rather than a prescription to perform work in a certain way or to achieve a certain

\footnotetext{
${ }^{40}[2013]$ VSC 105.
} 
result ${ }^{41}$ Her Honour derived support for this conclusion from the terms of $s$ 19(1) which 'draws a distinction between the concept of a ban, and the concept of performing work differently from the usual manner', the latter being a component of s 19(1)(a). ${ }^{42}$ It followed, in Her Honour's opinion, that the proposed industrial action was not protected under the FW Act, and she issued an interim injunction to restrain the CFMEU from committing the tort of inducing breach of contract.

Three months later, in FWC proceedings relating to the same dispute, a Full Bench dismissed an appeal by Energy Australia against a refusal by Bissett $C$ to issue a s 418 order to restrain the allegedly unprotected imposition of the ban on power generation. ${ }^{43}$ In the course of their decision the Full Bench observed:

To achieve the limitations on output the nature of the action would be that work the operators would normally do or is part of their normal duties will not be done. They will not operate the generators in the usual manner to that normally expected of them or as may be directed. The Commissioner was not in error, in our opinion, in the manner in which she dealt with the meaning to be ascribed to the words in the notice and, in that context, the use of the word bans. ${ }^{44}$

In reaching this conclusion the Full Bench distinguished the decision of Jessup $\mathrm{J}$ in Williams $v$ CFMEU $U^{45}$ on the grounds that in that case the Court had been dealing with the term 'ban, limitation or restriction' as used in former s 36 of the BCII Act. In the course of his opinion in that case, Jessup $\mathrm{J}$ cited with approval observations by Kirby $\mathrm{J}$ in Re Metal Trades Award 1952; Commonwealth Steel Co Ltd v Federated Ironworkers' Association of Australia to the effect that the term 'ban' refers to 'a total prohibition of all of the work described' and that the words 'limitation or restriction' were intended to 'catch any lesser interference'. ${ }^{46}$ Jessup $\mathrm{J}$ went on to add that the concept of a ban 'involves a prohibition which is absolute or categorical, and not merely a matter of inclination or preference'. ${ }^{47}$

The difference between the approach adopted by Jessup $\mathrm{J}$ in Williams and the Full Bench in Energy Australia is perhaps more apparent than real. In Jessup J's terms, to constitute a 'ban' for purposes of the then BCII Act, and by inference s 19 of the FW Act, the notified ban had to be 'total'. It was. It did not need to be a ban on all output, just output beyond the cut off prescribed in the notice, and during the hours notified. That being the case, the earlier decision of Hollingworth J appears, with respect, to be incorrect.

The ban issue aside, the concept of 'ban, limitation or restriction' is largely unproblematic. It has, for example, been found to encompass bans on working to new rosters which had (validly) been put in place by the employer; ${ }^{48}$ refusing to pump oil out of a 'Back Acter Pedestal' on-board a ship on unfounded occupational health and safety grounds, ${ }^{49}$ and

\footnotetext{
${ }^{41}$ Ibid, [35]. See also Ambulance Victoria v United Voice [2014] FCA 1119, [25].

42 Ibid, [36].

${ }^{43}$ Energy Australia Yallourn Pty Ltd v CFMEU [2013] FWCFB 3793.

${ }^{44}$ Ibid, [65].

45 [2009] FCA 223.

46 (1952) 74 CAR 84, 94.

47 [2009] FCA 223, [90].

${ }^{48}$ CEPU v Australian Postal Commission [2010] FMCA 688, [109].

${ }^{49}$ Offshore Marine Services Pty Ltd v MUA [2010] FWA 5196.
} 
refusal to work reasonable overtime in accordance with a relevant enterprise agreement or an applicable contractual arrangement. ${ }^{50}$

On the other hand, the definition has been found not to extend to giving notice of an intention to take industrial action on a particular day and then turning up for work on the day in question - so-called 'aborted industrial action'. ${ }^{51}$ As appears below, in David's Distribution Pty Ltd v National Union of Workers (David's Distribution) it was also found not to extend to at least some, possibly all, forms of picketing activity. ${ }^{52}$

\subsubsection{Section 19(1)(a)}

The interpretation of s 19(1)(a) raises rather more difficult issues. It will be recalled that to fall within the scope of that paragraph either:

- work must be performed in a manner different from that in which it is customarily or normally performed; or

- those taking the action must adopt a practice in relation to the work

such that the result is a restriction or limitation on, or a delay in the performance of work.

For conduct to fall within the scope of this definition, therefore, it is not enough to show that work is performed in a manner different from that in which it is customarily or normally performed, or that a practice has been adopted in relation to the work. It must also be shown that the requisite conduct has resulted in a restriction, limitation or delay in the performance of that work.

This form of words is clearly the linear descendent of para (a) of the definition of industrial action which was inserted in the C\&A Act in 1977, and has been a source of some difficulty for courts and tribunals which have been called upon to apply it since that time.

These difficulties are neatly encapsulated in the majority and dissenting opinions in Mornington Peninsula Shire Council (Mornington), ${ }^{53}$ and by the judgment of Tracey $\mathrm{J}$ in Ambulance Victoria v United Voice (Ambulance Victoria). ${ }^{54}$

In Mornington the Australian Nursing Federation (ANF) had applied for a PABO in respect of certain forms of proposed industrial action, including at paragraph 5 of the application, authorisation for 'distributing information to clients, and the media about the reason for the industrial action, and the wearing of campaign clothing'. Vice President Lawler granted the ANF's application.

\footnotetext{
${ }^{50}$ DP World Australia Ltd v MUA [2007] AIRC 646; AWU v Bluescope Steel Ltd [2008] AIRCFB 24; Pacific National Pty Ltd v Australian Rail, Tram and Bus Industry Union [2010] FWA 2884; Patrick Stevedores Holdings Pty Ltd v MUA [2015] FWC 3587 - cf CFMEU v BHP Coal Pty Ltd [2015] FCAFC 25.

${ }^{51}$ Re Boral Resources (NSW) Pty Ltd [2010] FWAFB 1771, [10]. See further Stewart et al, above n 2, [27.16].

52 (1999) 91 FCR 463.

${ }^{53}$ [2011] FWAFB 4809.

${ }^{54}$ [2014] FCA 1119.
} 
The employer sought, and was granted, leave to appeal against that decision. On appeal the Appellant acknowledged that there was no single decision dealing with communication to third parties as an iteration of industrial action, but submitted that '...the authorities in considering "industrial action" resulted in definitions which had at their heart a foundation in the performance, or non-performance of work' and that the proposed action in paragraph 5 did not meet the necessary connection to the performance of work. ${ }^{55}$

For its part, the ANF submitted that the wearing of campaign clothing was inconsistent with the employer's clothing policy, and that in the absence of approval from the employer, wearing such clothing 'would constitute "industrial action" within the meaning of s 19 of the Act', and that the communication contemplated by Question 5 'would occur whilst employees were working and would clearly fall within the meaning of "industrial action" involving a restriction, limitation or delay in the performance of work' ${ }^{56}$

A majority comprised of Watson SDP and Gooley C determined that the actions specified in Question 5 were 'capable, depending on the circumstances, of constituting "industrial action" within the meaning of s $19, .57$

More specifically, according to the majority, distribution of information to clients and the media might involve cessation or interruption of work and as such 'would clearly involve the performance of work by an employee in a manner different from that in which it is customarily performed', resulting in both a delay in the performance of work for purposes of s 19(1)(a) and a ban, limitation or restriction for purposes of s 19(1)(b). ${ }^{58}$

The majority also found that the wearing of campaign clothing was capable of constituting a ban, limitation or restriction for purposes of s 19(1)(b). ${ }^{59}$ In reaching this conclusion the majority observed that:

...the term 'the performance of work' within s 19(1)(b) of the Act is not restricted to how the tasks associated with a particular job are performed. It involves, for example when work is performed, where work is performed, how work is performed and the conditions under which work is performed. ${ }^{60}$

In the course of a vigorous dissenting opinion Kaufman SDP argued that neither the dissemination of information nor the wearing of campaign clothing came within either $\mathrm{s}$ 19(1)(a) or (b). ${ }^{61}$

Senior Deputy President Kaufman considered that the dissemination of information, even within working hours, 'says nothing about performing the work in a manner different from that in which it is usually performed or the adoption of a practice in relation to work', and 'there is nothing in the nature of the proposed conduct that suggests it would result in a restriction or limitation on, or a delay in, the performance of work' - although the situation

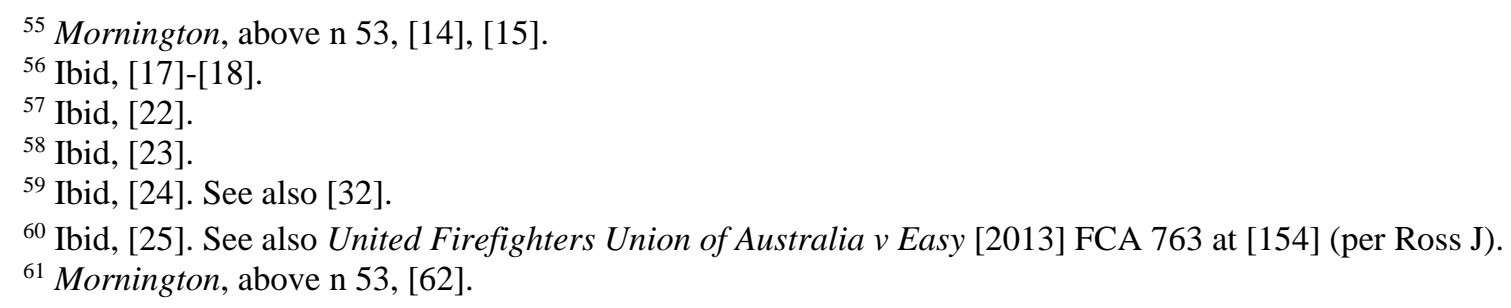


might have been otherwise 'had the proposed conduct been along the lines of say, a stoppage of work for 5 minutes per shift or per hour in order that information might be distributed'. ${ }^{62}$ As for s 19(1)(b), 'the dissemination of information is clearly not a ban, limitation or restriction on the performance of work' and as such did not fall within that limb of the definition. ${ }^{63}$

His Honour was also not persuaded that the wearing of campaign clothing was capable of falling within either s 19(1)(a) or (b). As concerns s 19(1)(a), it had 'nothing to do with the manner in which the work is performed, and could not affect the manner in which work was performed so as to result in a restriction, limitation or delay in the performance of work' ${ }^{64}$ It also did not constitute a ban, limitation or restriction on the performance of work, or on offering for or accepting work for purposes of s 19(1)(b). ${ }^{65}$

Justice Tracey in Ambulance Victoria was clearly much more comfortable with the position adopted by Kaufman SDP in Mornington than with that of the majority.

In Ambulance Victoria, United Voice sought approval for industrial action which contemplated the release to the public of ambulance response times. The FWC made a PABO permitting that question to be put to ballot. The proposed action was approved by the balloted employees, and in due course United Voice served notice on the employer that it proposed to release data to the media as contemplated by the ballot question. As Tracey $\mathrm{J}$ pointed out in the Federal Court, doing so would clearly constitute a breach of contract on the part of the employees concerned. ${ }^{66}$ Following service of the notice of protected action, the employer sought a Federal Court injunction to restrain the action on the grounds that the proposed release of the data did not constitute industrial action in the relevant sense. In the course of his judgment, Tracey $\mathrm{J}$ referred extensively to Mornington, and concluded that the constructions of s 19(1)(a) and (b) adopted by Lawler VP, and by the majority, were 'too broadly stated'. 67

His Honour gave a number of reasons for reaching that conclusion. The first was that the 'work' referred to in s 19 was not 'work' generally - rather the definition referred to work performed by 'an employee who is taking the relevant action'. ${ }^{68}$ In support of this proposition, he referred to the decision of the Full Court in David's Distribution and to the fact that Work Choices inserted the words 'by an employee' in what are now s 19(1)(a) and (b). ${ }^{69}$

In the opinion of Tracey $\mathrm{J}$, the use of this terminology means that:

\footnotetext{
${ }^{62}$ Ibid.

${ }^{63}$ Ibid, [63].

${ }^{64}$ Ibid, [64].

${ }^{65} \mathrm{Ibid},[65]$.

${ }^{66}$ Ambulance Victoria, above n 54, [5].

${ }^{67}$ Ibid, [19].

${ }^{68}$ Ibid, [20].

${ }^{69}$ Ibid, [22]. See also CFMEU v BHP Coal Pty Ltd, above n 50, [141].
} 
It is...necessary to identify work normally performed by the relevant employees and the manner in which it is customarily performed. The duties of the managers include the collection and analysis of information relating to response times of ambulances in their areas. It is not part of their duties to provide such information to persons outside ambulance Victoria, including reporters and others engaged by media outlets. It cannot, in my opinion, be said that making response time data available to the media, in breach of their contracts of employment, involves the performance of their normal work in a manner different from that in which it is customarily performed...The fact that the proposed action is contrary to contractual terms which are binding on the employees does not, for that reason, amount to the performance of duty in a manner different from the norm. Rules, policies and contractual provisions which proscribe conduct of certain kinds by employees regulate the conduct of those employees in the course of their employment. They do not impinge directly on the manner in which work is performed. A breach of such a proscription cannot, in my opinion, be regarded as a departure from the customary manner of performance of an employee's work. Were it otherwise, contraventions by employees of policies which prohibit sexual harassment or discrimination of various kinds could be regarded as departures from the customary manner of performance of work and thereby amount to industrial action. ${ }^{70}$

His Honour was confirmed in this view by the fact that the proposed action in this case:

...cannot in any relevant sense, be said to result in a restriction or limitation on or a delay in the performance of the employee's normal duties. What is proposed is the taking of action above and beyond and outside the range of their normal work rather than the placing of a restriction on the performance of those duties. ${ }^{71}$

Justice Tracey also agreed with Kaufman SDP in Mornington that 'the position might be different were the proposed conduct to include express provision for a stoppage of work, even for a short period, in order for the manager to distribute data to the media' ${ }^{72}$ In other words, to attract protection, it would be necessary for the employees concerned to stop work rather than do something which might (or might not) exert pressure on the employer without the dislocation involved in a work stoppage.

With respect, this line of reasoning is not entirely convincing. First, the harassment/discrimination example fails to take account of the reference in the legislative note to s 19(1) to the decision in AMWU $v$ The Age Company Limited ${ }^{73}$ to the effect that 'action will not be industrial in character if it stands completely outside the area of disputation and bargaining'. If, therefore, the sexual harassment/discrimination postulated by Tracey $\mathbf{J}$ fell outside the area of disputation and bargaining then it would lack the requisite 'industrial' character, and would not constitute industrial action for purposes of s 19(1)(a). ${ }^{74}$

Secondly, the approach adopted by his Honour does not seem to take adequate account of the fact that in the normal course of events the employees concerned would be performing their work in a manner which did not involve breach of their contracts of employment. By releasing data which they were not entitled to release they would be breaching their contract, and as such they would not be performing work in the manner in

\footnotetext{
${ }^{70}$ Ambulance Victoria, above n 54, [23].

${ }^{71}$ Ibid, [24].

${ }^{72}$ Ibid.

${ }^{73}$ PR946290, 11 May 2004. See further n 103 below.

${ }^{74}$ Note, however, that strictly speaking the passage referred to in the legislative note is obiter, see text accompanying $\mathrm{n} 105$ below.
} 
which it is customarily performed. This would be even more evident if it is assumed that the employees were given an express direction not to release the data, and they went ahead and did so in the face of a lawful reasonable direction not to do so.

Justice Tracey appears to be on firmer ground in finding that if the data were released there would be no restriction, limitation or delay in the performance of the employees' normal duties.

It will be recalled that in Mornington, the ANF argued that the communication contemplated by the PABO application would occur whilst employees were working and as such would involve a restriction, limitation or delay in the performance of work. The majority appears to have accepted this proposition, but did not set out their reasons for doing so. With respect, the proposition is not self-evident. If the release of the data in either Mornington or Ambulance Victoria would not involve any stoppage of work on the part of the employees concerned, and would not delay the performance of their normal duties, then it is hard to see how it could be said to constitute a restriction, limitation or delay for purposes of s 19(1)(a), even accepting that it constituted the performance of work in a manner different from that in which it was customarily performed.

Whatever conceptual difficulties may arise from the wording of section 19(1)(a), unions have exercised considerable ingenuity in adopting novel practices in relation to work or devising ways of performing work in a manner different from the way in which it is customarily performed, even though the link to restriction, limitation etc, or delay may sometimes seem somewhat tenuous.

For example, in $A S U v$ Lend Lease Bissett $\mathrm{C}$ was prepared to make a PABO seeking authorisation for:

- 'attaching, incorporating or distributing' campaign related material to outgoing correspondence and to the employer's materials and displays;

- 'wearing, distributing and posting union campaign material such as t-shirts, badges, written communications and stickers in support of the proposed enterprise agreement';

- not responding to non-emergency emails until after 1.00 PM each day, and placing an out of office notice indicating that the employee concerned was taking industrial action;

- adopting a similar course in relation to voice mails; and

- 'writing messages representing the concerns of Lend Lease staff regarding the EBA negotiations and process on Lend Lease...vehicles'. ${ }^{75}$

The fact that a particular form of action is included in a PABO application does not mean that, even if approved in a ballot, the action will necessarily fall within the definition of industrial action in s 19(1). ${ }^{76}$ In the Lend Lease case, for example, while all proposed forms

\footnotetext{
75 [2014] FWC 5676, [17].

${ }^{76}$ See eg Ambulance Victoria, above n 54, per Tracey J at [27].
} 
of action appeared to involve the performance of work differently from the manner in which it was customarily performed, only the third and fourth proposed actions clearly involved a 'restriction' or 'limitation' on the actual performance of work.

Other examples of 'exotic' forms of action, some of which have been included in PABO applications, but which would not necessarily constitute industrial action for purposes of $s$ include:

- airline pilots wearing red ties rather than company-issued ties while on duty; ${ }^{77}$

- making announcements relating to industrial negotiations via aircraft communication systems ${ }^{78}$

- refusal to participate in firm-related events outside working hours; ${ }^{79}$

- bans on saluting by firefighters; ${ }^{80}$

- responding to emails with the caps lock function turned on; ${ }^{81}$

- consuming meals and drinks during rest breaks in unoccupied management offices; ${ }^{82}$ and

- under cover of darkness, cutting the perimeter fence of a construction site and strewing lettuce leaves around the gaps in the fence in a partially successful attempt to induce feral kangaroos to enter the site. ${ }^{83}$

It must clearly be open to question whether some or all of these forms of action would be capable of having the result of a 'restriction or limitation' on the performance of work in the requisite sense.

\subsection{The strange case of picketing}

It was noted earlier that picketing is a significant feature of many industrial disputes. Theoretically, picketing would be lawful if it consisted of nothing more than attending at premises and peacefully communicating information, and as such would not require statutory protection. There is, however, authority which suggests that picketing is inherently unlawful, ${ }^{84}$ and in any event, even peaceful picketing will almost inevitably involve the torts of nuisance and trespass. If, as would often be the case, picketing involves interference with the movement of goods, services or people then it would inevitably involve further forms of tortious behaviour, and in some instances give rise to criminal liability, especially if violence

\footnotetext{
${ }^{77}$ AIPA v FWA (2012) 201 FCR 200, [47].

78 Ibid.

${ }^{79}$ ASU v Maurice Blackburn Pty Ltd [2016] FWC 4740.

${ }^{80}$ UFUA v CFA, PR569907, 29 July 2015.

81 Ibid.

${ }^{82}$ ASU v Central Highlands Water, PR576164, 18 January 2016.

${ }^{83}$ Mortimore v CFMEU [2010] FCA 537, [14]. This case arose out of an application for injunctive relief under s 39 of the BCII Act, but the definition of 'building industrial action' under that Act was relevantly the same as that in s 19 of the FW Act. See also Alfred v CFMEU [2011] FCA 556; Alfred v CFMEU [2011] FCA 557.

${ }^{84}$ See J Lyons \& Sons $v$ Wilkins [1899] Ch 255; Re Van der Lubbe (1949) 49 SR(NSW) 309; Sid Ross Agency Pty Ltd v Actors and Announcers Equity [1971] NSWLR 760. Cf Ward lock \& Co Ltd v Operative printers Assistants Society (1906) 22 TLR 327; CFMEU v BHP Coal Pty Ltd (2014) 253 CLR 243 at [58], [72] where the High Court characterised a particular picket as a 'lawful protest'.
} 
or damage to property was involved. ${ }^{85}$ That being the case, it may be assumed that respect for the right to strike requires that picketing activity should be protected against civil and criminal liability - at least so long as it remains peaceful. As noted earlier, that is certainly the position which has been taken by the supervisory bodies of the ILO. ${ }^{86}$

It has been determined, however, that that is not the position that has been adopted by the Australian Parliament.

In CFMEU v AIRC the Full Court of the Federal Court had significant doubts as to whether picketing could properly be regarded as industrial action within the definition of that term as it then stood, although it was not called upon to express a decided view on the matter at that time..$^{87}$

In the following year, in David's Distribution, a differently constituted Full Bench did need to express a decided view as to whether picketing fell within the definition of industrial action in the WR Act. Justices Wilcox and Cooper (with whom Burchett J relevantly agreed) started from the proposition that picketing which does not involve 'obstruction and besetting' did not fall within the definition of industrial action by reason of the fact that it does not relate to the performance of work in the circumstances specified in...the definition'. According to the plurality, such conduct did not need protection 'because it is not actionable by anyone' ${ }^{88}$

Turning to picketing which does involve obstruction and besetting, and which in consequence would require protection, Wilcox and Cooper JJ noted that:

Picketing which interferes with a person's liberty and freedom of movement infringes that person's common law rights; in particular, the right to free passage in public places and on public roads and footpaths...There is a presumption in the interpretation of statutes that there is no intention to interfere with common law rights or basic common law doctrine unless the words of the statute expressly or necessarily require that result...

To interpret para (c) of the definition of 'industrial action' in such a way as to include picketing infringing upon the rights and freedoms of others, would be to confer statutory immunity on such conduct; provided only it was engaged in upon proper notice to the employer and for the purposes of negotiating a certified agreement or an AWA. It would authorise interference with the rights, not only of the employer, but also of other affected persons who, but for the immunity, would have a right of action at common law... ${ }^{89}$

It will be recalled that at the time David's Distribution was decided, the definition of industrial action did not make any express reference to whether industrial action had to be taken by employees of the employer who was the target of the action. This meant that if picketing involved persons who were not employees of the target employer the action could, in principle, still fall within the scope of para (c) of the then-current definition of industrial action. This definition was amended by Work Choices to make clear that to constitute

\footnotetext{
${ }^{85}$ See further Creighton et al, above n 22, ch 36; McCrystal, above n 5, 99-101; Stewart et al, above n 2, [26.41$26.44]$ and [26.88].

${ }^{86}$ Text accompanying $\mathrm{n} 13$, above.

${ }^{87}$ (1998) 84 IR 314, 324-25.

88 (1999) 91 IR 198, [71]. See also [52].

${ }^{89}$ Ibid, [72]-[73].
} 
industrial action, the action had to be engaged in by the employees of the employer concerned. In other words, there was no longer any possibility that action by a third party (for example a truck driver engaged by a supplier who refused to cross a picket line to make deliveries) could constitute a ban, limitation or restriction in the relevant sense. ${ }^{90}$

The logical consequence of the decision in David's Distribution is that employees who picket their own place of work in the context of an industrial dispute are not protected against common law liability in respect of that picketing activity, even though they would be protected against liability in respect of any tortious conduct associated with other aspects of the industrial action - such as refusing to work or performing only part of their normal work. It also means that a truck driver who refused to cross a picket line would not be protected against common law liability deriving from that refusal - for example for breach of their contract of employment or the tort of conspiracy. And it means that workers from other workplaces who joined a picket line to show solidarity with their fellow workers would have no protection against civil or criminal liability, even if the picket was entirely peaceful.

Of course the fact that picketing does not constitute industrial action also means that such activity could not be constrained by orders under s 418 of the FW Act, and its predecessors. This exclusion is, however, likely to be of only marginal comfort to employees and unions in light of the fact that an employer that was targeted by pickets who engaged in conduct which went beyond the communication of information would have ready access to relief under common law and legislative provisions such as ss 45D-45DA of the Competition and Consumer Act 2010, not to mention the anti-coercion provisions in s 343 of the FW Act. ${ }^{91}$ Furthermore, there have been a number of instances where courts and tribunals have been prepared to make orders under s 418 and its predecessors even though the activity that was constrained consisted of picketing, and on the reasoning in David's Distribution was not industrial action. ${ }^{92}$ The fact remains, however, that David's Distribution has not been overruled, and unless or until that happens it must be regarded as good law. ${ }^{93}$

In 2015 the Heydon Commission recommended that the FW Act be amended so that picketing should be treated as industrial action for purposes of making orders under s $418 .{ }^{94}$ Interestingly, as Stewart et al point out, the Commission's Report did not contain any

\footnotetext{
${ }^{90}$ See, eg, Director, Fair Work Building Industry Inspectorate v CFMEU [2014] FCA 1373.

${ }^{91} \mathrm{See}$, eg, Co-Operative Bulk Handling Ltd v MUA [2013] FCA 940; Williams v AMWU (No 2) [2009] FCA 103 (involving the relevantly identical provision in s 44 of the BCII Act).

${ }^{92}$ See, eg, Transfield Construction v AMWU [2002] FCA 1413; CEPU v Australian Postal Corporation, Federal Court of Australia (Finkelstein J), V137 of 2004, 26 February 2004; Saint-Gobain Warehousing Pty Ltd v NUW [2006] NSWSC 1210, [11]. In Mortimore v CFMEU [2010] FCA 537 Tracey J was prepared at least to countenance the possibility that picketing could constitute building industrial action (at [16]-[17]).

${ }^{93}$ See Williams v AMWU (No 2) [2009] FCA 103. Note in particular Jessup J's discussion at [34]-[35] of the decision of Kenny J in Cahill v CFMEU [2008] FCA 1292, and his rejection of the suggestion that that case had distinguished David's Distribution. See also Director, Fair Work Building Industry Inspectorate v CFMEU [2014] FCA 1373.

${ }_{94}$ Royal Commission on Trade Union Governance and Corruption, Report, Vol 5, Commonwealth, Canberra, 2015, [190] and Recommendation 66(b).
} 
discussion of whether picketing in the context of otherwise protected industrial action should itself be protected. ${ }^{95}$

\subsection{Employer industrial action/Lockouts}

Section 19(1)(d) provides for just one form of employer industrial action, the lockout of employees from their employment by their employer, whilst s 19(3) defines lockout for this purpose in terms of an employer preventing its employees 'from performing work under their contracts of employment without terminating those contracts'.

From 1993 onwards federal industrial legislation recognised that it was lawful for employers to lock out employees in the course of enterprise bargaining. ${ }^{96}$ It was not until the Work Choices amendments of 2005, however, that the definition of industrial action contained an express differentiation between industrial action by employees and employers. ${ }^{97}$ This suggested that prior to Work Choices, action by an employer which constituted a 'ban restriction or limitation' on the work to be performed by employees could constitute 'industrial action' which, amongst other things could be protected under Division 8 of Part VIB of the WR Act, and could be 'prevented' in accordance with s 127. Clearly the concept of a 'ban' would include a lockout, and it seems reasonable to suppose that the terms 'restriction' and 'limitation' could encompass action falling short of a ban/lockout. ${ }^{98}$

Since 2009 the only form of employer industrial action contemplated by the federal Act has been the lockout. Clearly, this includes a full lockout where the employer denies employees the opportunity to perform work under their contracts of employment without those contracts being terminated.

The application of the definition to forms of employer conduct short of a full lockout is, more difficult. In particular, it is not clear whether the employer's preventing employees from working has to be total.

In $A M W U v$ Fletcher International Exports Pty Ltd (Fletcher), ${ }^{99} \mathrm{McDonald} \mathrm{C}$ found that the employer's alleged ban on rostering workers for voluntary overtime if they had engaged in protected industrial action was capable of constituting a lockout within the meaning of s 19(3). In reaching this conclusion, McDonald $\mathrm{C}$ relied on observations of Goldberg J in CFMEU v Master Builders' Association of Victoria (No 2) ${ }^{100}$ to the effect that

\footnotetext{
${ }^{95}$ Stewart et al, above $\mathrm{n} 2$, [26.26]. Section 47 of the BCIIP Act does, however, proscribe 'unlawful picketing' in the building and construction industry.

${ }^{96} \mathrm{See}$, eg, IR Act ss 170PG(3)-(6) and 170PI (2). Section 170PG(4) provided that the reference in s $170 \mathrm{PG}(3)$ to locking out employees was 'a reference to the employer preventing employees from performing work under their contracts of employment without terminating those contracts'.

97 WR Act s 420(3).

${ }^{98}$ See, eg, Australian Airline Flight Engineers' Association v Qantas Airways Ltd (1998) AIRC PRQ4688 $(7$ August 2008); Australian Federation of Air Pilots v Kendall Airlines (Australia) Pty Ltd (2002) AIRC PR920361.

99 [2013] FWC 7752.

100 (2000) 96 IR 274.
} 
'the imposition of a lockout allows an employer to limit or restrict the amount of work it will allow its employees to undertake'. ${ }^{101}$

The approach taken by McDonald $\mathrm{C}$ purports to recognise a 'ban, restriction or limitation on the performance of work' as a 'lockout' under s 19(3). With respect, this interpretation does not accord with either the letter or the spirit of the FW Act. It must surely be the case that if the legislature had intended that employer conduct consisting of a ban, restriction or limitation on the performance of work was to fall within the scope of s 19(3) it would have said so in express terms. In light of the fact that the FW Act draws a clear distinction between the various forms of employee conduct falling short of withdrawal of labour that is encompassed by s 19(1) and the employer's (undefined) right to lockout in s 19(3), it strains credulity to suggest that 'lockout' could encompass 'bans' or work restrictions falling short of a full lockout.

As with employee action which falls outside the statutory definition of industrial action, employer action which falls outside the scope of that definition could not be subject to the making of orders under ss 417 or 418 of the FW Act. Nevertheless, in principle it could constitute a breach of contract on the part of the employer, and conceivably could constitute 'coercion' for purposes of ss 343 or 348 of the FW Act. The authors are not aware of any case where the coercion point has been taken by an employee or a union.

The difference between the range of action available to employees and employers in $\mathrm{s}$ 19(1) was noted by the Productivity Commission in its 2015 inquiry into the workplace relations framework, and led the Commission to recommend the adoption of a broader concept of employer industrial action, including permitting more graduated forms of action, at least in the context of responding to employee industrial action. ${ }^{102}$

\subsection{The legislative note to $\mathrm{s}$ 19(1)}

As indicated earlier, a legislative note to s 19(1) refers to a passage in the decision of a Full Bench of the AIRC in Automotive, Food, Metals, Engineering, Printing and Kindred Industries Union $v$ The Age Company Limited to the effect that:

It seems to us likely that the legislature did not intend to include conduct which stands completely outside the area of disputation and bargaining and that accordingly the definition should be read giving some weight to the word industrial. But precisely how far this qualification might extend is a question of degree. We do not think it is desirable that we go further than is necessary to decide this case. ${ }^{103}$

'This case' involved an appeal by The Age Company against a s 127 order made by Whelan $\mathrm{C}$ directing it 'to cease and desist from engaging in or threatening to engage in industrial action' by terminating the employment of a specified category of employees by reason of redundancy. The proposed terminations arose in the context of the closure of a print facility in Melbourne, and the transfer of work to a new facility located close to Tullamarine

\footnotetext{
101 Ibid, 284.

102 See Productivity Commission, Workplace Relations Framework, Inquiry Report No 76, Productivity Commission, Canberra, 2015, 896-99.

${ }^{103}$ Reported as The Age Company Ltd v CEPU (2004) 133 IR 197, [46].
} 
Airport. Commissioner Whelan considered that the proposed terminations were 'both a ban on the performance of work by them [employees at the Spencer St facility] and a restriction on their ability to perform work in accordance with the enterprise agreement which governs their employment' within the meaning of paras (b) and (c) of the definition of industrial action as it then stood. ${ }^{104}$

The Full Bench rejected this line of reasoning. It gave three principal reasons for doing so:

- first, 'it would put undue strain on the language' to construe the definition of industrial action as meaning that conduct which brings employment to an end is industrial action. The concept of termination of employment is not the same thing as a 'ban, limitation or restriction on the performance of work';

- secondly, if the legislature had intended that the definition was to include termination of employment it would have said so in express terms; and

- thirdly, because 'the operation of the definition is predicated on the existence of an employment relationship or relationships pursuant to which various obligations are owed by each party to the other'. ${ }^{105}$

These grounds were sufficient to dispose of the case. It was not strictly necessary, therefore, for the Full Bench to go on to suggest that it was likely that the legislature did not intend that conduct 'which stands completely outside the area of disputation and bargaining' should constitute industrial action for purposes of the WR Act. Strictly speaking, therefore, these observations were obiter dicta.

Furthermore, even on their own terms, the Full Bench's observations did not state that 'action will not be industrial in character if it stands completely outside the area of disputation and bargaining'. As pointed out by Deegan C in Australian Capital Territory $v$ $A E U$ the Note 'tends to overstate the purport of the remarks made by the Full Bench, particularly given the context in which those remarks were made'. ${ }^{106}$ Commissioner Deegan also pointed to the fact that the Full Bench had expressly stated that the extent of the 'industrial' qualifier 'is a question of degree'. ${ }^{107}$

The Full Bench had clearly recognised that the concept of industrial action needed to be sufficiently flexible to accommodate some conduct which might not be strictly 'industrial' in character. To find otherwise would, for example, mean that action which was politically motivated would not be susceptible to the making orders under s 127 and its successors. ${ }^{108}$

It should also be noted that for 'employee claim action' to be protected under the FW Act it must be 'organised or engaged in for the purpose of supporting or advancing claims' in

\footnotetext{
${ }^{104}$ AMWU v The Age Company Limited, PR944259, 9 March 2004, [83].

105 (2004) 133 IR, [33], [34], [35] respectively.

106 [2010] FWA 3454, [31].

107 The expansive approach to the obiter comments in The Age Case is also supported by the Explanatory Memorandum for the Fair Work Bill 2008, [90].

${ }^{108}$ See, eg, CEPU v Laing (1998) 89 FCR 17; Secretary, Department of Education \& Early Childhood Development (Victoria) v AEU [2010] FWA 3775.
} 
relation to a proposed enterprise agreement, and that 'employer response action' must also be 'for a proposed enterprise agreement'. ${ }^{109}$ Since an enterprise agreement can be about only the permitted matters in s 172(1) of the FW Act - including matters pertaining to the relationship between an employer and its employees or an employer and a union - it follows that action which is not 'industrial' in character (because it does not pertain to the relationship between an employer and its employees and/or their union) could not be protected in any event. However, if action fell within the broader notion of 'industrial action' contemplated by decisions such as Laing then it would still be susceptible to the making orders under s 418, as well, of course, as at common law.

Overstated or not, the legislative note has been relied upon in a number of instances to determine that a particular course of conduct did not possess the requisite 'industrial' character. For example, in Boral Cement $v A W U$ it was used to support a finding that refusal to provide urine samples in the context of a contested drugs and alcohol policy did not constitute industrial action for purposes of s 418. ${ }^{110}$ Meanwhile, in Police Federation of Australia v Chief Commissioner of Police (Victoria Police) the applicant sought a s 418 order to restrain Victoria Police from redeploying members of a police band who had refused to accept a number of options for alternative work in the context of the 'privatisation' of the band. A Full Bench of the FWC rejected the application, and in doing so, endorsed the reasoning in The Age Case and the legislative note. ${ }^{111}$

By the same token, on a number of occasions the tribunal has used the obiter observations in The Age Case to support a finding that a particular course of action was industrial in character. For example, in AWU v Bluescope Steel Ltd a Full Bench of the AIRC found that a co-ordinated refusal to work optional extra shifts constituted industrial action, even though each individual employee had the right to refuse to work an extra shift when requested to do so. ${ }^{112}$

\subsection{The exclusions}

\subsubsection{Agreement}

Section 19(2)(a) and (b) contemplate the possibility that conduct which is agreed to by the other party does not constitute industrial action for purposes of either statutory protection or statutory proscription. This is consistent with the essential character of industrial action as action taken by a party (usually employees) to an industrial relationship to exert pressure on the other by doing, or not doing, something which disrupts the normal activities of the target party. If that party agrees to the conduct, then logically the action is not industrial in character. ${ }^{113}$

\footnotetext{
${ }^{109} \mathrm{FW}$ Act ss 409(1) and 410(1).

${ }^{110}$ [2012] FWAFB 350. See also CFMEU v Coal \& Allied Mining Services Pty Ltd [2008] AIRCFB 1159.

111 [2014] FWCFB 2063 at [50].

112 [2008] AIRCFB 24. See also Patrick Stevedores Holdings Pty Ltd v MUA [2015] FWC 3587; MUA v Patrick Stevedores Holdings Pty Ltd [2014] FWC 2651 at [187].

113 The employer-agreement exclusion was included in the original definition in 1977, and has been retained ever since. The employee agreement exclusion was inserted in 1988.
} 
Interestingly, the s 19 definition is entirely silent as to when or how 'agreement' is to be signified for these purposes. The fact that s 19(2)(a) and (b) are silent in relation to both issues leaves open the possibility that agreement could be provided after the action has occurred. It also leaves open the possibility that agreement could be inferred by conduct. It might be said, for example, that the act of paying wages in respect of a period where employees had been taking strike action constituted 'agreement' for purposes of s 19, with the consequence that seeking, accepting or making such payment would not be unlawful for purposes of Division 9 of Part 3-3. ${ }^{114}$

The authors are not aware of any case where an employer or union has sought to rely upon this reading of the s 19(2)(a) and (b) exclusions. Those cases where the exclusions have been raised have almost without exception been concerned with applications for s 418 orders, where the respondent has argued that orders should not be made due to the fact that the other party had agreed to the alleged industrial action, either in express terms or by making an enterprise agreement which authorised the action in question. Unsurprisingly, given that it is generally the employer who is seeking the order, such arguments have enjoyed a conspicuous lack of success. ${ }^{115}$

\subsubsection{Workplace health and safety}

In 1996 the definition of industrial action was amended by the insertion of an exclusion which was essentially the same as that now set out in s 19(2)(c). Work Choices adopted the same approach as the 1996 amendment, except that it inserted an onus of proof requirement such that if a person sought to rely on what is now the s 19(2)(c)(i) exclusion they had the burden of proving that that exclusion applied. ${ }^{116}$ That requirement was removed by the FW Act.

In its current form, the exclusion comprises four principal elements:

- the concern actuating those who take the action must be 'reasonable';

- the risk must be 'imminent';

- the risk must pertain to the actor's own health and safety, not that of a fellow-worker or some external person; and

- the person taking the action must not unreasonably fail to comply with a direction of their employer to perform other work, whether at the same or a different workplace, that is safe and appropriate for the employee to perform.

In AMWU $v$ Rheem Australia Pty Ltd Munro J suggested that 'the relevant industrial action must be based on the person taking the action having a genuine and reasonable belief about an imminent risk to the health and safety to that person'. ${ }^{117}$ In addition 'the action taken

\footnotetext{
${ }^{114}$ See further Stewart et al, above n 2, [26.69].

${ }^{115}$ See, eg, AWU v Bluescope Steel Ltd [2008] AIRCFB 24; United Voice v Foster's Australia Limited [2014] FWCFB 4104.

${ }^{116}$ Post-Work Choices WR Act s 420(4).

${ }^{117}$ PR921306, 9 April 2003, [46]. On the effect of failure to follow safety procedures, see Cahill v CFMEU [2008] FCA 495, [36], [38].
} 
must be proportionate to the risk', and 'dispute settlement procedures relevant to safety disputes at the site must have been fully complied with'. ${ }^{118}$

For a risk to be imminent 'there must be a probability of injury or harm occurring'. ${ }^{119}$ That in turn requires that 'there exists something more than the bare possibility that injury or harm...will occur from the activity in question'. ${ }^{120}$ This means, for example, that the exclusion will not apply in relation to action which genuinely related to WHS issues, but where those issues had been resolved. ${ }^{121}$

\section{Is $\mathbf{s} 19$ fit for purpose?}

As noted earlier, 'industrial action' was defined in the C\&A Act for the first time in 1977, and the core concepts enshrined in that definition remain in place today. However, the origins of many of those elements can be traced back well before 1977. For example, the concepts of 'bans, limitations or restrictions' on the performance of work, or upon 'acceptance of or offering for work' are clearly derived from the bans clauses which were such a prominent feature of the federal system in the decades before $1969 .{ }^{122}$ Similarly, the current reference to performing work 'in a manner different from that in which it is customarily performed' can be traced back to former proscriptions upon conduct which interfered with 'the performance of work in accordance with the award' ${ }^{123}$

Significantly, however, these concepts were all developed in a context where the legislative purpose was to proscribe industrial action, not to protect it. The current formula is used both to proscribe and to protect. It also tries to accommodate industrial tactics which are much more sophisticated than what HB Higgins famously described as the 'rude and barbarous processes of strike and lockout'. ${ }^{124}$ It is manifestly not up to the task.

This is evident, for example, from the difficulties the courts and tribunals have experienced in explicating the concept of a 'ban', let alone the performance of work in a manner different from that in which it is normally performed, or the adoption of a practice which results in 'a restriction or limitation on, or delay in, the performance of work'. Most revealing of all, perhaps, is the fact that, according to the Full Court of the Federal Court in David's Distribution, the concept of industrial action does not extend to picketing. This was a form of conduct that did not need to be proscribed under the traditional C\&A system because it did not relate to conduct which was governed by an award, and was already unlawful at common law and under State and Federal statute. ${ }^{125}$ With the adoption of a system which accords at least some level of recognition to the right to take industrial action in furtherance

\footnotetext{
${ }^{118}$ Ibid. See also CFMEU v Beltana Highwall Mining Pty Ltd [2012] FWA 2796, [76]-[77].

${ }^{119}$ Monadelphous Engineering Associates Pty Ltd v AWU AIRC, PR934966, 18 July 2003, [37].

${ }^{120}$ Ibid, [37]; citing Franklyn J in Wormald Security Australia Pty Ltd v Peter Rohan, Department of Occupational Health, Safety and Welfare (1993) 74 WAIG 2, 3.

${ }^{121}$ See, eg, Qantas Airways Limited v NUW [2007] AIRC 167; Offshore Marine Services Pty Ltd v MUA [2010] FWA 5196.

${ }^{122}$ See the text accompanying nn 21-22 above.

${ }^{123}$ This form of words was used in s 32(1)(a)(ii) of the C\&A Act at the time of its repeal in 1988.

${ }^{124}$ HB Higgins, 'A New Province for Law and Order' (1915) 29 Harvard Law Review 13, 13-14.

${ }^{125}$ See the sources cited at $\mathrm{n} 85$, above.
} 
of employees' occupational interests, it is clearly necessary to afford an appropriate level of legal protection to peaceful picketing.

With respect, the position adopted by the Full Court in David's Distribution was clearly based on a fundamental misunderstanding of the purpose of the statutory protections. It was precisely in order to 'authorise interference with the rights... of the employer' and 'other affected persons' that statutory protections were first adopted in the United Kingdom in $1906,{ }^{126}$ and in Australia in 1993. ${ }^{127}$

Taking the Court's reasoning on its own terms, it is hard to see that it is any less of an interference with an employer's common law rights to prevent them from suing striking workers (and their unions) for the torts of conspiracy, intimidation or interference with contractual relations than it would be prevent them from suing pickets for the torts of nuisance or trespass which were committed in the course of a picket.

The purpose of the statutory protections is to protect workers and unions against common law liability precisely because without such protection they would not be able to exercise their right to strike. If, therefore, picketing is to be denied statutory protection, it needs to be for a more plausible reason than, as suggested by Wilcox and Cooper JJ, respect for a presumption of statutory interpretation against interference with common law rights. The specious character of this line of reasoning becomes apparent when it is noted that the absence of statutory protection for picketing means that Australia is in breach of the international obligations incurred by adhering to the Constitution of the ILO, ratifying Convention No 87, and ratifying the ICESCR. ${ }^{128}$ Given that the legislation is capable of being interpreted in a manner that would protect peaceful picketing, the approach adopted by Wilcox and Cooper JJ clearly runs counter to the presumption of statutory interpretation that legislation is presumed not to violate the rules of international law. ${ }^{129}$

The end-result of all of this is that in its current form s 19 makes it impossible for employees, unions or employers clearly to determine what forms of action are capable of being protected under Part 3-3, and what forms of action are proscribed under the Act. It also means that certain forms of conduct which ought to be protected by reason of Australia's international obligations are denied protection.

This suggests that the FW Act needs to be amended to include a definition of employee industrial action which reflects three basic precepts:

- that the total or partial withdrawal of labour by employees constitutes employee industrial action;

- that employee industrial action also encompasses action which does not involve the total or partial withdrawal of labour, but which is intended, and has the capacity, to disrupt the normal functioning of all or part of an employer's business. It should be

\footnotetext{
${ }^{126}$ Trade Disputes Act 1906 (UK).

${ }^{127}$ Industrial Relations Reform Act 1993 (Cth) s 31.

${ }^{128}$ See McCrystal, above n 5, 242-243.

${ }^{129}$ See DC Pearce \& RS Geddes, Statutory Interpretation in Australia, $8^{\text {th }}$ ed, (Lexis Nexis, 2014), 229-30.
} 
irrelevant for these purposes whether the conduct actually disrupts the business and/or causes embarrassment or reputational damage to the employer. What matters is the capacity to disrupt, embarrass etc, and the intent to do so; and

- that picketing can constitute employee industrial action where employees attend at or near premises occupied by, or associated with, a target employer for the purpose of peacefully communicating information, including persuading third parties not to enter or leave the premises.

The definition also needs to make clear that the fact that third parties choose not to enter or leave premises does not deprive the conduct of the pickets of its character as employee industrial action, and does not in itself constitute industrial or unlawful action on the part of those third parties who elect not to enter or leave the premises.

A definition of employee industrial action reflecting these precepts would dispense with the need to establish that conduct constitutes a 'ban' in 19(1)(b), and the double pronged requirement in s 19(a) that action be both work performed in a manner different to which it is customarily performed and constitute a restriction, limitation or delay in the performance of work. Instead, the focus would shift to whether there was a total or partial withdrawal of labour (a 'strike'), or conduct which was intended, and had the capacity, to disrupt the normal functioning of an employer's business.

In Energy Australia for example, action to limit the output of generators to 240 megawatts at certain times of the day would be action intended to disrupt the normal functioning of an employer's business - given that the operation of the business is not normally subject to any such limitation. There would be no need to consider whether the conduct constituted a 'ban', or to engage in the kind of semantic exercises upon which those decisions turned.

As concerns the issues associated with the more creative forms of industrial action noted earlier, such action would constitute 'industrial action' if the requirement that it constitute a restriction, limitation or delay in the performance of work were removed. As indicated, action such as the communication of information to the media, the addition of campaign messages to emails or voice mail messages, writing emails in caps lock or the wearing of campaign clothing will not generally restrict, limit or delay the normal performance of work, even where it is intended to do so - but it would disrupt the normal operation of the business. This means, for example, that an employee could be disciplined for breaching a company code of conduct prohibiting such behaviour even if it were undertaken as a part of a campaign of protected industrial action that would not fall within the second limb of the definition in s 19(1)(a). A definition focused on an intention to disrupt, irrespective of a requirement actually to do so, would mean that such actions would be captured and protected where they constituted part of a campaign of protected industrial action.

Where industrial action involves a picket, a definition encompassing these precepts would overcome the dubious distinction that must be drawn as a result of David's 
Distribution between employees refusing or failing to perform any work at all - which is industrial action - and those same employees standing on a picket whilst refusing to work and peacefully communicating information or attempting to persuade others not to cross a picket - which is not. Such a dichotomy leads to the absurd outcome that an employee is protected against dismissal or other adverse consequences in respect of the withdrawal of their labour, but not with respect to otherwise peaceful protest activities undertaken whilst their labour is withdrawn. ${ }^{130}$ Further, while it would extend protection to otherwise peaceful activity undertaken on a picket, it would also ensure that a picket could be subject to an order under ss 417 or 418 where it constituted unprotected industrial action.

As noted earlier, the supervisory bodies of the ILO have not treated the employer's capacity to lockout its workforce as the logical corollary of the worker's right to strike. Nevertheless, many legal systems, including Australia's, do just that. ${ }^{131}$ The present authors are not persuaded that it is appropriate to treat the two phenomena as two sides of the same coin. ${ }^{132}$ The right to strike provides workers with industrial power to counter that held by employers through the law of contract and property, rights related to managerial prerogative and the ability transnationally to move assets and jobs. A right of lockout is not necessary to provide parity at the bargaining table. Nevertheless protection of such a 'right' is a reality, and it seems most unlikely in political terms that a Government of any political complexion would seek to remove legal protection from employer lockouts whilst retaining protection for employee action. Accepting that reality, it does seem anomalous that the only tactic available to employers should be a full lockout. Logically, if employers are to have the capacity to lockout in response to employee claim action they should also be able to engage in action short of a lockout - such as banning the working of overtime, withholding contractual bonuses, or withdrawing concessions such as cut-price access to goods or services produced by the employer. Recognising that employer industrial action can include conduct of this kind might be seen to increase the bargaining power of employers, but it would also mean that employers could respond to low-key employee industrial action without the cost and dislocation for employers, employees and the community which would commonly be associated with a lockout. ${ }^{133}$

Accepting, without condoning, the parity approach, a revised definition of employer industrial action could legitimately include the current s 19(1)(d) and (3), but should also seek to accommodate employer conduct which is intended, and has the capacity, to disrupt

\footnotetext{
${ }^{130}$ See eg CFMEU v BHP Coal Pty Ltd (2014) 253 CLR 243 where an employee was found lawfully to have been terminated from his employment due to his conduct on a picket which was considered by the employer to breach company policy. While the employee concerned was not technically engaged in protected industrial action at the time he participated in the picket (as he was rostered off), it would not have made any difference if he had been engaging in such action because the picket did not constitute industrial action and therefore was not protected.

${ }^{131}$ See further Chris Briggs, 'Lockout Law in a Comparative Perspective: Corporatism, Pluralism and NeoLiberalism' (2005) 21 International Journal of Comparative Labour Law and Industrial Relations 481.

${ }^{132}$ For discussion of the flawed logic which underpins the parity of legal treatment of strikes and lockouts, see Novitz, above n 9, 7-8.

${ }^{133}$ See eg Schweppes Australia Pty Ltd v United Voice - Victorian Branch (No 1) (2011) FWA 9329 (155 employees locked out for 58 days in response to notification of a range of work bans and stoppages of between 60 minutes and 24 hours).
} 
the performance of work by employees - irrespective of whether such disruption actually results from the employer's conduct. Such an approach would capture the type of employer conduct challenged in Fletcher, as a ban on rostering workers who had engaged in industrial action for voluntary overtime would constitute a response to worker industrial action, undertaken to disrupt the performance of work and capacity to earn an income of those workers. Crucially, while it would permit such action to occur as part of a campaign of employer response industrial action, it would also clarify that such conduct was industrial action for the purposes of s 418, enabling a trade union to obtain an order preventing the conduct where it was not protected industrial action. However, it would not extend to legitimate managerial decisions over business structure, redundancy or re-deployment of employees, where such decisions were not retaliatory or intended to disrupt the performance of work by employees.

\section{Conclusion}

As noted at the outset, the concept of 'industrial action' plays a critical role in the functioning of key provisions of the FW Act, including providing the basis for legislative protection against common law and statutory liability for organising or participating in industrial action, providing a basis for orders to restrain unprotected action, providing the trigger for withholding wages of participants in industrial action, and enabling the standing down of employees in certain circumstances. It can only be a matter for regret, therefore, that the definition of that term is not more clearly drawn.

Changes to the definition of industrial action of the character outlined above should provide the basis for the legislation clearly to identify the circumstances in which employees and employers could, and could not, lawfully take industrial action. This appears to provide a rather more rational basis both for protecting those forms of industrial action which ought to be protected, and for proscribing those forms of industrial conduct which ought to be proscribed, than the present agglomeration of relics from the bygone days of the conciliation and arbitration system and conceptual confusion as to the legitimate role of industrial action in a democratic society. This in turn would make it much easier to adopt a regulatory regime which is consistent with international human rights standards, and industrial reality, than is presently the case in Australia. 